\title{
INVESTASI DAERAH DAN E-GOVERNMENT SERTA IMPLIKASINYA TERHADAP KEMANDIRIAN DAERAH
}

\author{
Nunuy Nur Afiah, Sri Mulyani, Ibnu Hamzami Ulfi* \\ Fakultas Ekonomi, Universitas Padjadjaran, Indonesia
}

\begin{abstract}
Regional independence is still homework for most local governments, as can be seen from small contributions of most local governments. This study aims to examine empirically the effect of regional investment and e-government on regional independence with samples of 33 provinces in Indonesia in 2019. Regional investment is measured by the amount of long-term investment in the balance sheet, while e-government is measured by the results of the SPBE evaluation. Data processing is using IBM SPSS 26 software with multiple regression analysis methods with qualified requirements in the classical assumption test. Based on the calculation of regional investment, there is a significance value of 0.015. The value is $<0.05$ so it can be concluded that regional investment has significant effects on regional independency. These results can also be interpreted that funds which are invested by local governments to local companies can contribute in increasing the local income. However, different results were obtained by the e-government variable which produced a significant value of 0.080 and the value is $>0.05$, so it can be concluded that e-government has no significant effect on regional independency. These results of study are expected to provide recommendations to local governments to invest continuously in regional companies, especially to those that are productive in generating profits, fixing and improving the electronic-based public services, especially concerning in increasing local income as an important element in regional independence.
\end{abstract}

\section{Keywords: local revenue, long-term investment, SPBE}

\begin{abstract}
Kemandirian daerah nyatanya sampai saat ini masih menjadi pekerjaan rumah bagi sebagian besar pemerintah daerah, terlihat dari kontribusi pendapatan asli daerah yang masih relatif kecil di sebagian besar pemerintah daerah. Penelitian ini bertujuan untuk mengkaji secara empiris pengaruh dari investasi daerah dan e-government terhadap kemandirian daerah dengan sampel 33 Provinsi di Indonesia tahun 2019. Investasi daerah diukur dengan jumlah investasi jangka panjang dalam laporan neraca dan e-government diukur dengan hasil evaluasi SPBE. Pengolahan data menggunakan software IBM SPSS 26 dengan metode analisis regresi berganda dengan terlebih dahulu memenuhi persyaratan dalam uji asumsi klasik. Berdasarkan hasil perhitungan investasi daerah didapat nilai signifikansi sebesar 0,015 dan nilai tersebut $<0,05$, sehingga dapat disimpulkan bahwa investasi daerah berpengaruh signifikan terhadap kemandirian daerah. Hasil tersebut juga dapat diartikan bahwa dana yang diinvestasikan oleh pemerintah daerah kepada perusahaan daerah mampu memberikan kontribusi dalam meningkatkan pendapatan asli daerah. Namun hasil berbeda didapat oleh variabel e-government yang menghasilkan nilai signifikansi sebesar 0,080 dan nilai tersebut >0,05, sehingga disimpulkan bahwa e-government tidak berpengaruh signifikan terhadap kemandirian daerah. Hasil penelitian ini diharapkan dapat memberikan rekomendasi kepada pemerintah daerah untuk dapat terus berinvestasi kepada perusahaan daerah, terutama yang produktif dalam menghasilkan laba dan berupaya memperbaiki serta meningkatkan pelayanan publik berbasis elektronik, terutama dalam kaitannya dengan peningkatan pendapatan asli daerah sebagai unsur penting dalam kemandirian daerah.
\end{abstract}

Kata kunci: pendapatan asli daerah, investasi jangka panjang, SPBE

Klasifikasi JEL: H1, M48 


\section{PENDAHULUAN}

Pemerataan pembangunan di Indonesia dapat dicapai dengan otonomi daerah, karena daerah diberikan tanggung jawab serta kesempatan yang lebih besar dan luas untuk dapat mengatur daerahnya sendiri dan mengelola keuangannya yang disesuaikan dengan kebutuhan masyarakat setempat. Sehingga diharapkan mampu membuat daerah menjadi lebih mandiri dalam mengurus segala keperluan urusan pemerintahannya. Namun konsekuensi lain dari otonomi daerah ialah pemerintah daerah (pemda) dituntut mampu mencari sendiri sumbersumber penerimaan keuangan dengan didasarkan kepada potensi daerah yang dimiliki, yang kemudian digunakan seluas-luasnya untuk membiayai seluruh urusan pemerintahan daerahnya termasuk dalam hal pembangunan (Ahmad, 2011; Ndaparoka et al., 2018). Kondisi tersebut mencerminkan tercapainya tujuan dari otonomi daerah yaitu kemandirian. Andriani \& Wahid, (2018); Saleh (2020); Tahar \& Zakhiya (2011) serta Tolosang (2018) menyatakan bahwa pendapatan asli daerah erat kaitannya dengan kemandirian suatu daerah. Oleh karenanya bagaimana kemampuan pemda mencari sumber-sumber penerimaan yang ada di daerah dan mampu mengelolanya dengan baik tentu sangat diharapkan.

Namun nyatanya, setelah berjalan selama 20 tahun, otonomi daerah dapat dikatakan belum sepenuhnya berjalan dengan baik. Terlihat dari masih banyaknya daerah-daerah yang sangat bergantung kepada pemerintah pusat dalam hal keuangan. Badan Pemeriksa Keuangan Republik Indonesia (2020) menyampaikan bahwa sebagian besar daerah saat ini masih tergolong belum mandiri secara finansial.

Tabel 1. Persentase Pendapatan Asli Daerah (PAD) 2018-2020

\begin{tabular}{lllllll}
\hline \multirow{2}{*}{ PAD } & \multicolumn{2}{c}{2018} & \multicolumn{2}{c}{2019} & \multicolumn{2}{c}{$2020^{*}$} \\
\cline { 2 - 7 } & Pemda & $\%$ & Pemda & $\%$ & Pemda & $\%$ \\
\hline $0 \%-25 \%$ & 480 & 88,56 & 477 & 88,01 & 473 & 87,27 \\
\hline$>25 \%-50 \%$ & 50 & 9,23 & 54 & 9,96 & 55 & 10,15 \\
\hline$>50 \%-75 \%$ & 11 & 2,03 & 10 & 1,85 & 13 & 2,40 \\
\hline$>75 \%-100 \%$ & 1 & 0,18 & 1 & 0,18 & 1 & 0,18 \\
\hline Total & 542 & 100 & 542 & 100 & 542 & 100 \\
\hline \multicolumn{7}{c}{ Sumber: DJPK Kemenkeu (diolah) }
\end{tabular}

Terlihat pada tabel 1 bahwa sebagian besar pemerintah daerah memiliki porsi PAD yang kecil terhadap total pendapatan daerah, 87 persen pemerintah daerah pada tahun 2020 memiliki kontribusi PAD dibawah 25 persen. Walaupun angka tersebut menunjukkan penurunan dibandingkan tahun sebelumnya, namun kondisi tersebut perlu menjadi perhatian serius, karena mencerminkan sebagian besar pemerintah daerah masih membutuhkan pembiayaan yang bersumber dari pemerintah pusat dalam menggerakkan roda pemerintahannya. Hal ini tentu menjadi beban yang sangat besar bagi pemerintah pusat, terlebih lagi di masa sulit seperti saat pandemi sekarang ini. Sejalan dengan penjelasan di atas, Martini et al (2019) mengatakan saat ini di dalam struktur Anggaran Pendapatan dan Belanja Daerah (APBD) kebanyakan pemerintah daerah di Indonesia mengalami kontribusi pendapatan asli daerah yang relatif kecil.

Peningkatan kemandirian pemerintah daerah dapat dicapai melalui peningkatan realisasi pendapatan daerah (Normalita \& Mahmud, 2017; Ruliana, 2015; Saleh, 2020). Mandirinya suatu daerah berarti pemerintah daerah akan lebih leluasa menentukan arah serta kebijakan dalam pengelolaan keuangan daerah untuk ditujukan dalam membangun daerah serta menyejahterakan masyarakat setempat tanpa adanya intervensi dari pihak siapapun selama tidak bertentangan dengan ketentuan perundang-undangan. Kebijakan mengoptimalkan pendapatan asli daerah 
dapat ditempuh dengan berbagai upaya, namun secara umum ada dua cara utama yang dapat dilakukan, yaitu intensifikasi dengan menghitung kembali seakurat mungkin dan ekstensifikasi yaitu mengadakan penggalian sumber-sumber baru objek penerimaan daerah (Firdausy, 2017). Salah satu cara ekstensifikasi adalah dengan mengalokasikan sebagian dananya untuk dilakukan investasi dengan tujuan bisa mendapatkan keuntungan di kemudian hari, sehingga dapat membantu berkontribusi terhadap pendapatan asli daerah. Investasi mempunyai peranan penting untuk pembangunan ekonomi (Mirsan et al., 2019). Salah satu bentuk investasi adalah dengan penyertaan modal kepada perusahaan daerah atau lebih dikenal dengan BUMD.

Peran BUMD sangat penting karena dapat memberikan pelayanan yang tidak mampu diberikan oleh pemerintah daerah, dan juga dapat menjadi lapangan pekerjaan bagi masyarakat setempat. Sehingga penyertaan modal tersebut akan sangat membantu BUMD dalam menjalankan usahanya karena akan meningkatkan permodalan perusahaan yang dapat digunakan untuk meningkatkan aset serta kapasitas produksi, baik itu dari segi barang maupun jasa. Kapasitas produksi yang meningkat berarti peningkatan juga dalam output yang dihasilkan untuk kemudian dijual dan diharapkan mendapatkan keuntungan yang maksimal. Pemerintah daerah selaku pihak yang berinvestasi akan mendapatkan sebagian keuntungan tersebut yang kemudian diakui sebagai pendapatan asli daerah. Dari penjelasan tersebut dapat disimpulkan bahwa investasi mampu berkontribusi terhadap pendapatan daerah. Uraian tersebut didukung oleh penelitian yang dilaksanakan oleh Maulizar et al (2017) dengan melihat bagaimana hasil penyertaan modal (investasi) yang ditempatkan Pemerintah Provinsi Aceh di Bank Aceh ternyata mampu membantu meningkatkan produktivitas perusahaan sehingga berdampak pada peningkatan pendapatan perusahaan tersebut. Laba yang diperoleh oleh Bank Aceh mampu berkontribusi terhadap pendapatan asli daerah (PAD). Terjadinya peningkatan pendapatan asli daerah tentu akan berdampak secara langsung kepada peningkatan kemandirian daerah (Saleh, 2020).

Namun berdasarkan Ringkasan Neraca Tahun 2019 yang dirilis oleh Kementerian Keuangan, sampai saat ini investasi pemerintah daerah masih tergolong kecil bahkan ada beberapa daerah yang tidak melakukan investasi. Permasalahan lainnya adalah bagaimana kontribusi dari BUMD itu sendiri yang kurang berperan sebagai sumber pendapatan, padahal tujuan didirikannya perusahaan-perusahaan daerah adalah untuk memperoleh keuntungan yang kemudian dapat digunakan untuk pembangunan daerah (Nugraha, 2019). Nurmiati et al (2019) menyatakan hal yang serupa, bahwa realisasi keuntungan dari BUMD selama ini belum ada yang mencapai target yang telah ditetapkan. Menjadi salah satu bagian dalam pendapatan asli daerah, nyatanya selama ini keberadaan perusahaan daerah belum mampu menjadi kontributor utama bagi penerimaan daerah (Maulizar et al., 2017). Padahal sebagian besar BUMD mendapatkan sumber daya yang melimpah yang dipercayakan untuk dikelola sebaik mungkin namun tidak kunjung membuahkan hasil sehingga memberikan kontribusi yang kurang diharapkan (Kelbulan, 2015).

Prof. Bambang selaku Guru Besar di IPB (Zulfikar, 2021) menyampaikan bahwa peran BUMD saat ini tergolong masih rendah, seharusnya hasil dari BUMD dapat membantu APBD. Triyanto (2017) menyampaikan hal serupa bahwa di Kalimantan Barat, penyertaan modal daerah (investasi daerah) tidak terlalu berkontribusi secara substansial terhadap pendapatan asli daerah (PAD) karena hanya beberapa perusahaan daerah saja yang mampu berkontribusi dengan menghasilkan laba, seperti BUMD yang bergerak dalam perbankan seperti BPD, namun selebihnya belum mampu berkontribusi seperti yang diharapkan.

Ekstensifikasi penerimaan pendapatan dapat dibantu dengan teknologi. Seperti yang terlihat saat ini bahwa teknologi telah menawarkan suatu kemudahan dalam proses pekerjaan menjadi lebih efisiensi, efektif, adanya perbaikan tata kelola serta peningkatan dalam kinerja. Melihat manfaat ini, pemerintah di seluruh dunia mulai mencoba memfokuskan perhatiannya terhadap penerapan teknologi dalam kegiatan pemerintahan atau dikenal dengan istilah $e$ - 


\section{8 | Bina Ekonomi}

government. E-Government telah menjadi suatu konsep yang familiar sebagai bagian dari berkembangnya teknologi informasi dan komunikasi. Transisi dari pemerintahan yang tradisional menjadi pemerintahan berbasis elektronik sepertinya tidak bisa dihindarkan lagi. Teknologi memungkinkan organisasi publik mendapatkan efisiensi melalui penyederhanaan dan otomatisasi pengiriman layanan, dan memungkinkan warga untuk bisa memberikan umpan balik mengenai kebijakan publik dan berdiskusi secara online dengan pejabat yang bersangkutan dan warga lainnya (Manoharan \& Ingrams, 2018).

Masyarakat saat ini mulai mengharapkan mendapatkan pelayanan publik di pemerintahan seperti layanan perbankan online atau belanja online (Benjamin \& Potts, 2018) dan salah satu urusan yang akan berdampak dengan hadirnya teknologi adalah pengelolaan perpajakan dan retribusi daerah. Penggunaan teknologi saat ini memungkinkan masyarakat membayar pajak atau retribusi dengan cara yang simpel dan mudah, cukup dengan membuka aplikasi yang telah disediakan dari smartphone yang terhubung dengan internet maka masyarakat sudah dapat melakukan pembayaran pajak atau retribusi secara online tanpa harus datang langsung. Efisiensi proses tersebut diharapkan mampu meningkatkan partisipasi dan kontribusi publik dalam membayar pajak daerah maupun retribusi daerah. Penggunaan teknologi juga berarti dapat menjangkau ke daerah yang lebih luas sehingga penerimaan pajak menjadi lebih besar (Edmiston, 2003). Peran e-government dalam meningkatkan pendapatan daerah dapat ditemukan dari penelitian yang dilakukan oleh Purwokoadi (2014) yang melihat bagaimana hasil cash administration setelah diterapkannya e-government pada proses pembayaran pajak kendaraan bermotor dengan hasil penelitian yaitu e-government ternyata mampu dan memiliki pengaruh yang positif dan signifikan terhadap kinerja cash administration. Namun hasil negatif dari penerapan e-government terlihat dari penelitian yang dilakukan oleh Rahmatunnisa et al (2021) yang meneliti terkait "Efektivitas Pelayanan Permohonan Perizinan Mendirikan Bangunan dengan Berbasis Elektronik Serta Kontribusinya Pada Pendapatan Asli Daerah di Kalimantan”, yang menghasilkan kesimpulan bahwa retribusi izin mendirikan bangunan dengan berbasis elektronik masih dirasa sangat kurang kontribusinya terhadap pendapatan asli daerah.

Beberapa penelitian terdahulu telah meneliti variabel-variabel tersebut, namun masih terbatas pada wilayah tertentu saja yang lebih kecil dan tidak secara nasional, sehingga tidak bisa diambil kesimpulan secara umum terkait kondisi pemerintah daerah di Indonesia. Selain itu beberapa penelitian terdahulu hanya melihat bagaimana penerapan e-government pada satu sisi saja seperti hanya melihat dari segi pajak atau retribusi daerah. Sedangkan penelitian ini bertujuan untuk mengkaji kembali secara empiris apakah investasi daerah dan implementasi $e$ government di pemerintah daerah mampu berkontribusi dalam meningkatkan kemandirian daerah dengan menggunakan 33 Provinsi sebagai sampel dan juga dengan menggunakan hasil evaluasi SPBE yang mencerminkan secara keseluruhan keadaan implementasi e-government di suatu pemerintah daerah, sehingga akan didapatkan gambaran utuh terkait kondisi yang sebenarnya di pemerintah daerah di Indonesia. Manfaat penelitian ini adalah untuk memberikan wawasan serta pandangan baru terhadap implikasi dari investasi daerah dan e-government terhadap kemandirian pemerintah daerah di Indonesia serta dapat memberikan masukan serta bahan evaluasi bagi pemerintah daerah dalam membuat kebijakan atau keputusan terkait investasi daerah, penerapan e-government serta upaya dalam membantu meningkatkan pendapatan asli daerah sehingga tercipta kemandirian daerah.

\section{TINJAUAN LITERATUR}

\section{Stewardship Theory}


Teori Stewardship merupakan suatu teori yang merefleksikan suatu kondisi di mana para manajemen tidak terdorong oleh tujuan-tujuan secara individu tetapi lebih ditujukan kepada pencapaian tujuan secara bersama demi yang lebih besar yaitu kepentingan organisasi (Sudaryo et al., 2017). Berdasarkan teori ini, pada hakekatnya manajemen selalu ingin melaksanakan pekerjaan dengan sebaik mungkin dan ketika terjadi suatu pertentangan maka pihak steward tidak berusaha menentangnya karena merasa bahwa kepentingan bersama lebih diutamakan dan merupakan usaha yang dinilai rasional dalam mencapai tujuan organisasi.

Teori Stewardship mampu diaplikasikan pada bidang akuntansi sektor publik, dan semenjak perkembangannya, akuntansi sektor publik memang disiapkan guna memenuhi kebutuhan informasi bagi hubungan antara pelayan dengan principals (Sudaryo et al., 2017). Pemerintah pada dasarnya ditujukan untuk melayani masyarakat demi mencapai suatu keadaan yang sejahtera. Karenanya institusi pemerintah memiliki kewajiban serta tanggung jawab untuk memberikan pelayanan yang prima dan profesional.

Teori ini juga yang mendasari bahwa pemerintah daerah bertanggung jawab terus berupaya dalam memberikan pelayanan yang optimal kepada masyarakat. Upaya tersebut dapat dilakukan dengan cara melakukan investasi kepada perusahaan daerah agar perusahaan tersebut dapat bekerja secara optimal dan melakukan ekspansi usahanya dalam rangka melayani dan menjangkau masyarakat yang lebih luas. Selain itu pemerintah juga memberikan kemudahan dalam berinteraksi dan bertransaksi dengan menghadirkan layanan publik berbasis elektronik. Terlaksananya pemerintahan dan pelayanan publik yang baik oleh pemerintah daerah akan menimbulkan rasa aman dan timbul kepercayaan dari masyarakat terhadap pemerintah. Sehingga mendorong masyarakat untuk lebih berpartisipasi memilih pelayanan yang ditawarkan oleh pemerintah yang tercermin dalam peningkatan penerimaan daerah. Tingginya penerimaan daerah kemudian akan dibelanjakan lagi dalam berbagai kegiatan seperti untuk menanggulangi kemiskinan, pemerataan pembangunan masyarakatnya, sehingga dapat dikatakan bahwa tingkat kemandirian daerah termasuk upaya dalam dalam menyejahterakan masyarakatnya.

\section{Otonomi Daerah, Kemandirian Daerah dan Pendapatan Asli Daerah}

Berlakunya otonomi daerah dan desentralisasi fiskal berarti terjadinya pemberian wewenang dari pemerintah pusat ke pemerintah daerah untuk kemudian menjadi tanggung jawab daerah tersebut. Otonomi daerah menjadikan pemerintah daerah saat ini memiliki tanggung jawab yang lebih luas dalam mengatur daerahnya secara mandiri, termasuk juga dalam urusan pembangunan daerah. Yuliandriansyah (Patarai, 2018) menyebutkan bahwa pilihan terbaik dalam rangka mendorong kemandirian serta pembangunan daerah yang efektif dan efisien adalah dengan otonomi daerah. Secara prinsipiil, kewenangan yang diberikan kepada pemerintahan daerah, ditujukan untuk mengoptimalkan penyelenggaraan fungsi-fungsi utama pemerintahan yang mencakup pelayanan (service), pemberdayaan (empowerment) serta pembangunan (development) dengan tujuan untuk memberikan keadilan dan pemerataan bagi masyarakat (Patarai, 2018).

Dengan pendekatan berbasis wilayah, dimungkinkan untuk lebih memperhatikan dan melihat potensi sumber daya alam maupun manusia yang dimiliki, perkembangan teknologi, sosial ekonomi dan budaya, letak geografis, dan lainnya dari sudut daerah. Sehingga pemerintah daerah perlu menggali dan memanfaatkan aset-aset yang dimilikinya agar lebih berdaya guna, dan juga harus bisa melaksanakan pembangunan secara inovatif dan kreatif untuk menjawab tantangan kemandirian ekonomi tersebut sehingga ketergantungan terhadap pemerintah pusat dapat diminimalisir.

Ketergantungan fiskal telah ditengarai sebagai salah satu faktor penghambat keberhasilan pembangunan pasca-pelaksanaan otonomi daerah (Ahmad, 2011). Oleh karenanya pemerintah 


\section{0 | Bina Ekonomi}

daerah saat ini telah dituntut mulai berfokus dan memperhatikan bagaimana caranya dalam meningkatkan kontribusi Pendapatan Asli Daerahnya (PAD) sebagai upaya mencapai kemandirian daerah (Tolosang, 2018). Pendapatan asli daerah sangat erat kaitannya dengan kemandirian daerah (Andriani \& Wahid, 2018; Handayani \& Erinos, 2020; Tahar \& Zakhiya, 2011; Tolosang, 2018). Mangantar (2018) menyatakan bahwa kemandirian keuangan daerah dapat mempengaruhi kesejahteraan masyarakat, sehingga upaya untuk meningkatkan pendapatan asli daerah harus menjadi prioritas penting bagi pemerintah daerah.

Untuk dapat mewujudkan tujuan dari otonomi daerah tersebut serta memperkuat struktur keuangan dalam APBD, maka kontribusi PAD perlu untuk terus ditingkatkan karena merupakan salah satu ukuran kemampuan daerah serta cerminan dari kemandirian keuangan daerah (Sari et al., 2018). Ruliana (2015) serta Normalita \& Mahmud (2017) menyatakan bahwa tingkat kemandirian pemerintah daerah dapat dilakukan melalui peningkatan realisasi pendapatan daerah. Kemandirian disini dapat diartikan bahwa pendapatan asli daerah telah mampu untuk membiayai hampir semua kegiatan pemerintahan serta pembangunan dengan hanya dengan sedikit bantuan dari pemerintah pusat. Semakin mandiri suatu wilayah maka pemerintah daerah setempat akan lebih leluasa dalam mengelola keuangannya tanpa ada intervensi dari pihak lain selama tidak bertentangan dengan ketentuan peraturan yang ada. Beberapa penelitian terdahulu seperti yang dilakukan oleh Andriani \& Wahid (2018); Tahar \& Zakhiya (2011) serta Tolosang (2018) mempertegas hal tersebut dengan menyatakan bahwa secara signifikan pendapatan asli daerah mempengaruhi kemandirian daerah.

Kemandirian keuangan daerah di setiap pemerintah daerah menunjukkan tingkat pencapaian otonomi daerah dan desentralisasi fiskal, yaitu terciptanya kesejahteraan masyarakat (Normalita \& Mahmud, 2017). Hal penting dengan hadirnya otonomi daerah adalah pemerintah daerah dapat lebih fokus dalam peningkatan kualitas pelayanan publik, penurunan tingkat kemiskinan dan pengangguran, pemerataan pendapatan dan memperkecil kesenjangan. Karena tugas utama dari pemerintah adalah untuk menyejahterakan masyarakatnya.

\section{Investasi Daerah dan Pengaruhnya Terhadap Kemandirian Daerah}

Pemerintah daerah di Indonesia perlu mengkaji keseriusan dalam mengelola anggaran dan pendapatan daerah seperti yang dilakukan di beberapa negara maju (Suratno, 2018). Oleh sebab itu, perlu diberlakukannya upaya-upaya yang bertujuan meningkatkan Pendapatan Asli Daerah sehingga tercipta kemandirian daerah antara lain dengan cara berinvestasi. PP No 63 Tahun 2019 menyatakan bahwa investasi daerah dapat dilakukan dengan menempatkan sejumlah dana dalam kurun waktu yang panjang ke dalam bentuk surat berharga maupun secara langsung untuk memperoleh manfaat di masa selanjutnya.

Salah satu bentuk investasi yang dapat ditempuh oleh pemerintah daerah adalah dengan penyertaan modal secara langsung kepada perusahaan daerah atau dikenal dengan nama BUMD dengan harapan mendapatkan sebagian keuntungan di kemudian hari. Investasi oleh pemerintah akan sangat membantu BUMD dalam meningkatkan pelayanan dan ekspansi usahanya karena perusahaan akan memiliki kecukupan modal yang dapat digunakan dalam meningkatkan produktivitasnya sehingga akan menghasilkan output yang lebih besar yang kemudian akan menghasilkan laba. Modal merupakan persoalan utama dalam menggerakkan kegiatan suatu badan usaha, karena menyangkut dengan keseluruhan harta yang dapat diputar untuk kelangsungan usaha (Maulizar et al., 2017). Oleh karenanya analisis yang mendalam sebelum dilakukannya keputusan terkait investasi akan sangat diperlukan dan akan membantu pemerintah dalam menentukan perusahaan mana yang layak diberikan penyertaan modal dan mampu memberikan keuntungan bagi pemerintah. 
Pemerintah daerah dalam berinvestasi harus memperhatikan prinsip-prinsip transparansi, akuntabilitas, independensi, kewajaran, kesetaraan, profesionalitas serta kehatihatian. Selain itu perencanaan pembangunan daerah juga perlu diperhatikan dalam menentukan alokasi investasi yang bertujuan untuk memperbaiki penggunaan sumber daya publik yang tersedia di daerah (Kusmayadi, 2015). Oleh karenanya sebelum keputusan kebutuhan investasi dibuat, pemerintah harus melakukan evaluasi kebutuhan investasi yang diperlukan terlebih dahulu. Mardiasmo (2018) menjelaskan hal-hal yang perlu diperhatikan dalam proses evaluasi penentuan kebutuhan investasi adalah: "1) Inventarisasi investasi, yang memuat daftar nama dan jenis nilai investasi, kondisi, barang modal yang saat ini ada, apakah baik ataukah buruk; 2) memeriksa cakupan layanan dengan investasi yang sekarang ada; 3) tambahan cakupan layanan yang dibutuhkan saat ini dan masa yang akan datang; 4) Inventarisasi kebutuhan investasi; dan 5) evaluasi kelayakan investasi meliputi aspek-aspek teknis, sosial-budaya, finansial, ekonomi dan aspek distribusi".

Investasi daerah pada Badan Usaha Milik Daerah (BUMD) seharusnya mampu berkontribusi terhadap penerimaan daerah. Kontribusi tersebut tentu akan meningkatnya jumlah penerimaan pendapatan asli daerah sehingga mampu meningkatkan juga kemandirian daerah. Oleh karenanya salah satu aspek yang perlu diberdayakan adalah investasi daerah (Wahyono, 2021). Sehingga dapat dirumuskan suatu hipotesis sebagai berikut:

$\mathrm{H}_{1}$ : Investasi daerah berpengaruh secara signifikan terhadap kemandirian daerah

\section{E-Government dan Pengaruhnya Terhadap Kemandirian Daerah}

Di era serba digital seperti saat ini, dorongan akan penggunaan teknologi terasa begitu kuat, tidak terkecuali dalam bidang pemerintahan. Secara sederhana e-government dapat didefinisikan sebagai penggunaan teknologi informasi oleh pemerintah dalam melaksanakan tugas pemerintahan dan pelayanan publik (Rokhman, 2011). Penggunaan teknologi tersebut memungkinkan organisasi publik mendapatkan efisiensi melalui penyederhanaan dan otomatisasi pengiriman layanan, dan juga memungkinkan warga untuk bisa memberikan umpan balik mengenai kebijakan publik dan berdiskusi secara online dengan pejabat yang bersangkutan dan warga lainnya (Manoharan \& Ingrams, 2018). Diharapkan dengan penerapan teknologi tersebut bisa menghasilkan transisi proses kerja yang lebih simpel, responsif, adanya keterbukaan, akuntabel, serta mampu mengurangi kecurangan dan menjadi solusi atas permasalahan yang selama ini terjadi di pemerintahan.

Pada hakikatnya e-government adalah untuk perbaikan tata kelola pemerintah dengan bantuan teknologi (kominfo.go.id, 2019) dengan mengubah sistem kerja dari yang semula manual menjadi sistem kerja secara elektronik. Oleh karena itu selama proses transisi tersebut perlu dikelola dan dievaluasi dengan benar sehingga bisa berjalan lancar. E-Government umumnya dikonsep sebagai penggunaan Teknologi Informasi dan Komunikasi (TIK) oleh pemerintah yang dikombinasikan dengan perubahan organisasi untuk meningkatkan struktur dan operasi pemerintahan (Twizeyimana \& Andersson, 2019). Jauhari et al (2015) dan Sutopo et al (2017) menyatakan bahwa terjadinya peningkatan kinerja pemerintah daerah karena adanya dampak positif dari diterapkannya e-government.

Di Indonesia istilah Sistem Pemerintahan Berbasis Elektronik (SPBE) digunakan untuk merujuk kepada e-government. Sistem Pemerintahan Berbasis Elektronik merupakan komitmen pemerintah Indonesia dalam mereformasi birokrasi serta upaya dalam mendukung percepatan implementasi Elektronifikasi Transaksi Pemerintah Daerah (ETPD) yang bertujuan untuk mengoptimalkan penerimaan daerah, transparansi pengelolaan keuangan daerah serta mendukung diterapkannya transaksi digital oleh masyarakat umum, meningkatkan integrasi 


\section{2 | Bina Ekonomi}

ekonomi, mewujudkan keuangan yang inklusif seperti yang tercantum dalam Keppres No 3 Tahun 2021.

Contoh peningkatan pendapatan daerah berbasis elektronik dapat terlihat dari upaya Pemerintah Kota Bandung dalam meningkatkan pajak restoran dengan menggunakan alat tapping box. Seperti yang dikutip dari merdeka.com (2018) bahwa Pemerintah Kota Bandung menempatkan sejumlah tapping box (alat yang berfungsi untuk merekam setiap transaksi) di sejumlah lokasi seperti hotel, restoran, maupun tempat hiburan dan dengan alat ini setiap transaksi tercatat secara real time ke dalam sistem perpajakan Pemerintah Kota Bandung, alat ini juga dapat berfungsi untuk meminimalkan kebocoran pajak. Kepala BPPD Kota Bandung Ema Sumarna (merdeka.com, 2018) mengatakan pada tahun 2016 lalu Pemerintah Kota Bandung mengadakan tapping box senilai $\mathrm{Rp} 2,75$ miliar dan mampu memperolehkan pajak restoran/tempat hiburan sebesar Rp 24,5 miliar. Hal ini tentu menjadi suatu pencapaian yang fantastis dan menjadikan bukti nyata bahwa penggunaan teknologi dalam kegiatan pemerintah mampu berkontribusi dalam pendapatan asli daerah (PAD). Hasil serupa didapatkan oleh Bahtiar et al (2021) yang melaksanakan penelitian di Jawa Barat dengan melihat bagaimana implementasi e-government serta dampaknya terhadap pembayaran pajak kendaraan bermotor berbasis aplikasi di Jawa Barat. Hasil dari penelitian ini menyebutkan bahwa terjadi hubungan yang positif dari layanan aplikasi yang digunakan yaitu SAMSAT Mobile terhadap realisasi penerimaan pajak dan ini meningkat setiap tahunnya.

Berdasarkan uraian di atas serta hasil dari sejumlah penelitian terdahulu yang menyatakan bahwa teknologi mampu berkontribusi meningkatkan penerimaan pendapatan asli daerah (PAD) dan secara langsung akan mempengaruhi tingkat kemandirian daerah. Sehingga dapat dirumuskan suatu hipotesis sebagai berikut:

$\mathrm{H}_{2}$ : Implementasi e-government memiliki pengaruh secara signifikan terhadap kemandirian daerah

Berdasarkan uraian serta didukung dengan teori yang ada, maka dapat dibuatkan kerangka pemikiran seperti pada gambar berikut ini:

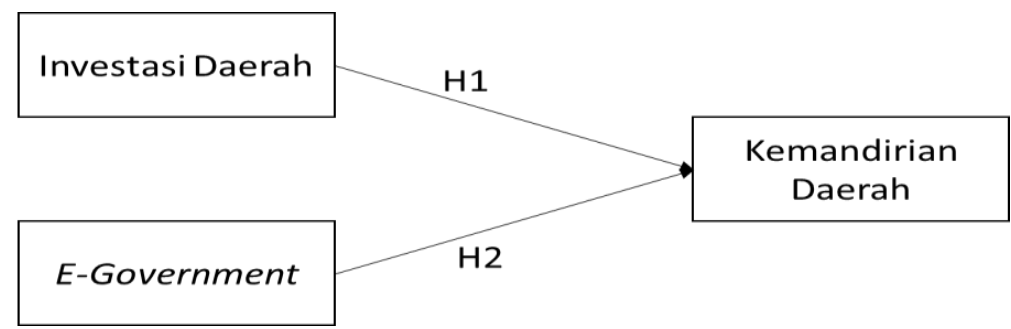

Gambar 1. Kerangka Pemikiran

\section{METODE DAN DATA}

\section{Populasi dan Sampel}

Pemerintah Provinsi di Indonesia menjadi populasi yang digunakan dalam penelitian ini yang berjumlah 34 Provinsi dengan rentang waktu observasi selama satu tahun yaitu tahun 2019 . Diharapkan dengan digunakannya pemerintah daerah tingkat Provinsi dapat mewakili dan merepresentasikan keadaan pemerintah daerah secara utuh di Indonesia. Teknik sampling yang digunakan pada penelitian ini ialah purposive sampling dengan beberapa kriteria sebagai berikut 
yaitu: 1) Provinsi yang Laporan Neraca tahun 2019 dipublikasikan oleh Kementerian Keuangan; 2) Provinsi yang hasil evaluasi SPBE tahun 2019 dipublikasikan oleh Kementerian Pemberdayaan Aparatur Negara dan Reformasi Birokrasi (MENPANRB); 3) Provinsi yang hasil Indeks Kemandirian Fiskal tahun 2019 dipublikasikan oleh Badan Pemeriksa Keuangan Republik Indonesia (BPK RI). Berdasarkan kriteria tersebut didapatkan sampel sejumlah 33 Provinsi dengan data observasi berjumlah 33 data. Provinsi yang tidak dijadikan sampel adalah Provinsi Papua karena hasil Indeks Kemandirian Fiskalnya tidak ada, selain itu dikarenakan keterbatasan data yang tersedia untuk tahun 2020 tidak dapat diteliti.

\section{Jenis dan Sumber Data}

Jenis data yang digunakan dalam penelitian ini adalah data sekunder, yang diambil dari beberapa laporan seperti Laporan Neraca, Laporan Hasil Reviu Kemandirian Fiskal dan Rekapitulasi Hasil Evaluasi SPBE. Data dan laporan tersebut diperoleh peneliti dari berbagai instansi pemerintah yang bertanggung jawab dalam menghimpun data-data tersebut, yaitu: Kementerian Keuangan, Kementerian Pemberdayaan Aparatur Negara dan Reformasi Birokrasi (MENPANRB), serta Badan Pemeriksa Keuangan Republik Indonesia (BPK RI).

\section{Pengukuran Variabel}

Pada penelitian ini kemandirian daerah adalah variabel dependen $(\mathrm{Y})$ yang diukur dari hasil evaluasi Indeks Kemandirian Fiskal (IKF) yang dikeluarkan oleh Badan Pemeriksa Keuangan sedangkan variabel independennya adalah Investasi Daerah (Inv_D) yang diukur dengan jumlah investasi jangka panjang yang tercantum dalam neraca yang dipublikasikan oleh Kementerian Keuangan dan e-government yang diukur dengan hasil evaluasi SPBE yang dipublikasikan oleh Kementerian Pemberdayaan Aparatur Negara dan Reformasi Birokrasi.

\section{Kemandirian Daerah}

Kemandirian daerah dapat diartikan sebagai kondisi yang menggambarkan suatu daerah yang mampu mengurus berbagai urusan pemerintahannya secara mandiri dengan menggunakan pembiayaan yang berasal dari pendapatan asli daerah. Hal tersebut juga merupakan suatu kondisi yang mencerminkan tingkat kebutuhan suatu daerah terhadap sumber dana yang berasal dari luar daerahnya (eksternal) atau dalam hal ini adalah pemerintah pusat. Kemandirian suatu daerah dapat dihitung dengan menggunakan rasio kemandirian. Jika hasil rasio tersebut rendah mengindikasikan bahwa pemerintah daerah masih sangat membutuhkan bantuan pemerintah pusat dalam membiayai kegiatan pemerintahannya, namun jika hasil semakin tinggi hasil perhitungan rasio kemandirian menunjukkan bahwa pemerintah daerah telah mampu membiayai semua urusan pemerintahannya dengan menggunakan sumber pendapatan asli daerahnya. Rasio kemandirian juga dapat merepresentasikan bagaimana peran masyarakat dalam membangun daerah yang dapat terlihat dari nilai realisasi penerimaan pajak daerah, retribusi daerah serta penerimaan lain sebagai salah satu unsur utama pendapatan asli daerah (Patarai, 2018).

Kemandirian daerah diukur dengan cara menghitung rasio kemandirian fiskal. Perhitungan rasio kemandirian fiskal dalam penelitian ini menggunakan rumus yang digunakan oleh Badan Pemeriksa Keuangan dalam menghitung Indeks Kemandirian Fiskal (IKF). Rumus perhitungan IKF adalah dengan menggunakan rumus yang dikembangkan oleh Hunter (1977) namun disesuaikan dengan kondisi APBD di Indonesia yang sedikit berbeda dengan struktur yang digunakan oleh Hunter (1977), sedangkan untuk klasifikasi hasil perhitungan digunakan klasifikasi yang dikembangkan oleh Sampurna (2018) seperti dikutip dari Laporan Hasil Reviu 2019 BPK RI yang terdiri dari empat klasifikasi yaitu: "belum mandiri, menuju mandiri, mandiri dan sangat mandiri”. Rumus perhitungan IKF adalah sebagai berikut: 
$I K F=1-\frac{\operatorname{Tr} G P+\operatorname{Tr} S P+B+R E V S H}{R E V O R+\operatorname{Tr} G P+\operatorname{Tr} S P+B+R E V S H}$

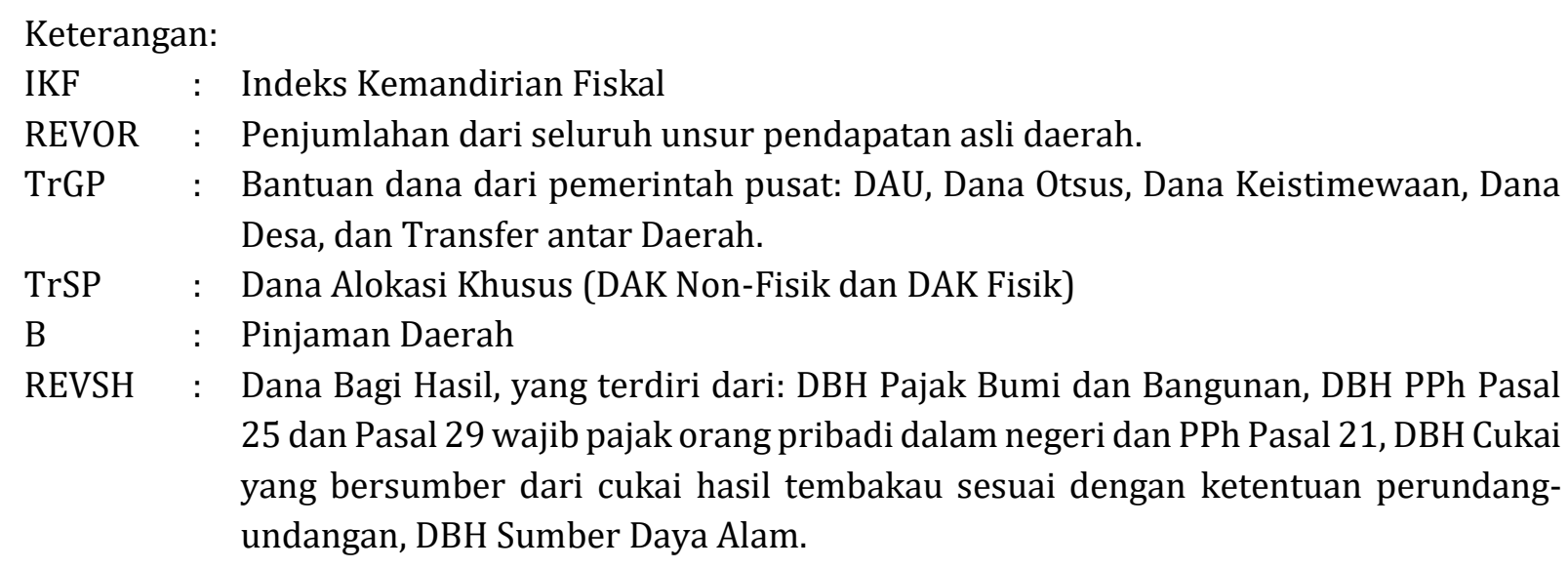

\section{Investasi Daerah}

PP No 63 Tahun 2019 tentang Investasi Pemerintah menjelaskan bahwa investasi adalah "menempatkan sejumlah dana dalam kurun waktu tertentu ke dalam instrumen keuangan seperti surat berharga maupun dapat dilakukan secara langsung dengan tujuan memperoleh manfaat di masa mendatang".

Definisi tersebut jelas menyatakan bahwa penempatan sejumlah dana oleh pemerintah daerah dengan tujuan untuk mendapatkan keuntungan sehingga dapat membantu berkontribusi dalam pendapatan asli daerah yang kemudian dapat digunakan untuk menyejahterakan masyarakatnya dan juga pembangunan daerah. Sehingga dapat disimpulkan bahwa investasi daerah memiliki kontribusi dalam meningkatkan pendapatan asli daerah (PAD).

Variabel investasi daerah dalam penelitian ini diukur dengan jumlah dana yang dialokasikan (penyertaan modal) oleh pemerintah daerah di akun investasi jangka panjang yang tercantum dalam Laporan Neraca.

Inv_D = $\sum$ inv. jangka panjang (non permanen + permanen)

Keterangan:

Inv_D : Investasi Daerah

\section{E-Government}

Secara sederhana e-government adalah digunakannya teknologi informasi dan komunikasi dalam kegiatan operasional pemerintahan (Rokhman, 2011). E-Government di Indonesia merujuk pada istilah Sistem Pemerintahan Berbasis Elektronik (SPBE) berdasarkan Perpres No 95 Tahun 2018 dan untuk melihat bagaimana tingkat kematangan (maturity level) dari pelaksanaan SPBE di instansi pemerintahan maka dilakukan penilaian evaluasi SPBE dengan merujuk kepada Permenpanrb No 5 Tahun 2018 sebagai dasar evaluasi. Evaluasi tersebut juga sebagai salah satu sarana untuk dapat memberikan rekomendasi perbaikan. Struktur domain, aspek dan indikator merupakan tiga struktur utama yang dinilai dalam mengevaluasi SPBE dengan masing-masing diberikan bobot dan skor untuk dinilai.

Hasil evaluasi akan menggambarkan tingkat kematangan pelaksanaan SPBE secara keseluruhan di suatu pemerintah daerah. Ada lima tingkatan terkait maturity level SPBE yaitu 
memuaskan, sangat baik, baik, cukup dan kurang. Semakin tinggi nilai indeks SPBE yang didapatkan oleh suatu pemerintah, baik pusat maupun daerah maka merepresentasikan bahwa pemerintah tersebut telah memiliki tata kelola pemerintahan berbasis elektronik yang baik, efektif, efisien, menghasilkan komunikasi dua arah bagi penggunanya, adanya integrasi dengan aplikasi lain, akuntabel, serta terjaminnya keamanan datanya. Semua hal tersebut sesuai dengan prinsip SPBE. Secara sederhana rumus perhitungan SPBE dapat diilustrasikan sebagai berikut:

Indeks $S P B E_{i t}=($ domain $1 \times$ bobot $)+($ domain $2 \times$ bobot $)+($ domain $3 \times$ bobot $)$

Domain $_{n}=\left(\frac{\text { nilai bobot aspek } n}{\text { total bobot domain } n} \times\right.$ nilai aspek $)+\left(\frac{\text { nilai bobot aspek } n}{\text { total bobot domain } n} \times\right.$ nilai aspek $)+\mathrm{n}$

Aspek $_{n}=\frac{\text { Nnilai indikator }}{\text { jumlah } \text { indikator }}$

\section{Metode Analisis}

Penelitian ini dalam menganalisis data digunakan metode uji statistik deskriptif dan juga regresi linier berganda dengan bantuan software IBM SPSS 26. Kemudian dilanjutkan dengan menguji asumsi klasik dengan empat tahap uji yaitu uji normalitas, autokorelasi, multikolinearitas serta heteroskedastisitas. Uji asumsi klasik diperlukan untuk melihat data dalam penelitian yang diobservasi harus berdistribusi normal, untuk menghindarkan bias dan tidak boleh ada hubungan antara masing-masing variabel independen di dalam suatu model regresi berganda (Chandrarin, 2017). Serta uji hipotesis yang memenuhi syarat uji koefisien determinasi, uji $F$ dan uji $t$. Berdasarkan uraian diatas sebelumnya, dapat dibuatkan model rumus perhitungan regresi berganda untuk pengujian hipotesis 1 dan 2 sebagai berikut:

$I K F i t=\alpha+\beta_{1} I N V_{-}$Dit $+\beta_{2}$ SPBEit $+e$

Keterangan:

$\begin{array}{ll}\text { IKFit } & : \text { Indeks Kemandirian Fiskal pemda i pada tahun } \mathrm{t} \\ \alpha & : \text { Konstanta } \\ \beta_{1,2} & \text { : Koefisien regresi } \\ \text { SPBEit } & \text { : Indeks SPBE pemda i pada tahun } \mathrm{t} \\ \text { Inv_Dit } & \text { : Jumlah investasi pemda i pada tahun } \mathrm{t} \\ \mathrm{e} & \text { : Tingkat kesalahan penduga dalam model ini }\end{array}$

\section{PEMBAHASAN}

\section{Statistik Deskriptif}

Berdasarkan metode pemilihan sampel di atas, digunakan 33 Pemerintah Provinsi sebagai sampel dengan 33 data observasi. Hasil pengujian statistik deskriptif di bawah ini menunjukkan nilai minimum, maksimum, rata-rata dan standar deviasi variabel penelitian yang dapat dilihat pada tabel 2 berikut ini:

Tabel 2. Hasil Statistik Deskriptif

\begin{tabular}{lrrrrr}
\hline & $\mathrm{N}$ & \multicolumn{1}{c}{ Minimum } & \multicolumn{1}{c}{ Maximum } & \multicolumn{1}{c}{ Mean } & \multicolumn{1}{c}{ Std. Deviation } \\
\hline INV_D & 33 & 4064.88 & 61410334.18 & 3535613.57 & 10687000.24 \\
SPBE & 33 & 1.00 & 3.85 & 2.46 & 0.74 \\
IKF & 33 & 0.04 & 0.71 & 0.36 & 0.16
\end{tabular}




\section{6 | Bina Ekonomi}

Valid N (listwise) 33

Sumber: olah data SPSS (2021)

Keterangan:

INV_D : Investasi Daerah (dalam jutaan rupiah)

SPBE : Sistem Pemerintahan Berbasis Elektronik

IKF : Indeks Kemandirian Fiskal

Berdasarkan tabel 2 terlihat nilai investasi daerah terkecil adalah 4.064,88 (dalam jutaan rupiah) yang merupakan nilai investasi di Provinsi Maluku Utara sedangkan nilai investasi yang terbesar adalah 61.410.334,18 (dalam jutaan rupiah) yang merupakan nilai investasi daerah di Provinsi DKI Jakarta. Rata-rata variabel SPBE menghasilkan nilai 2,46 (dibulatkan) dan jika merujuk kepada tabel tingkatan kematangan akan didapatkan hasil tingkatan cukup. Nilai tersebut dapat dimaknai bahwa pelaksanaan e-government di Indonesia telah dilaksanakan dengan cukup baik dengan sifat layanan yang bersifat dua arah, pelaksanaan didasarkan dengan dasar-dasar manajemen, namun layanan yang diberikan sebatas berdasarkan standar unit organisasi masing-masing dan belum secara menyeluruh. Provinsi dengan nilai Indeks SPBE tertinggi adalah Provinsi Jawa Tengah dengan nilai 3,85, sedangkan yang terendah adalah Provinsi Maluku Utara dengan nilai 1,00. Selanjutnya nilai rata-rata untuk Indeks Kemandirian Fiskal (IKF) Provinsi di Indonesia adalah 0,36 (dibulatkan) dan jika diinterpretasikan dengan menggunakan tabel klasifikasi dikutip dari Laporan Hasil Reviu 2019 BPK RI maka posisinya berada di tingkat kondisi menuju mandiri artinya pendapatan asli daerah sudah mulai dapat berkontribusi namun secara umum masih membutuhkan pembiayaan yang berasal dari pemerintah pusat. Hasil Indeks Kemandirian Fiskal tertinggi pada tahun 2019 diraih Provinsi DKI Jakarta dengan nilai 0,71 yang artinya sudah mampu membiayai urusannya dengan hasil pendapatan asli daerah sedangkan dana dari pusat hanya sebatas dana perbantuan dan Provinsi dengan nilai IKF terendah didapat oleh Provinsi Papua Barat. Terlihat masih terjadi kesenjangan yang begitu besar terutama antara daerah di wilayah timur dengan daerah di wilayah barat Indonesia, khususnya wilayah yang berada di Pulau Jawa.

\section{Uji Asumsi Klasik}

Uji Normalitas

Tabel 3. Hasil Uji Normalitas

\begin{tabular}{lcr}
\hline \multicolumn{2}{c}{ One-Sample Kolmogorov-Smirnov Test } \\
\hline $\mathrm{N}$ & \multicolumn{2}{c}{ Unstandardized Residual } \\
Normal Parameters ${ }^{\mathrm{a}, \mathrm{b}}$ & & 33 \\
& 0.000 & 0.000 \\
Most Extreme Differences & 0.136 & 0.107 \\
& 0.094 & 0.096 \\
& 0.094 & 0.078 \\
Test Statistic & -0.074 & -0.096 \\
Asymp. Sig. (2-tailed) & & 0.094 \\
Sumber: olat daata SPSS & & $0.200^{\mathrm{c}, \mathrm{d}}$ \\
\hline
\end{tabular}

Sumber: olah data SPSS (2021)

Pengujian pertama dalam uji asumsi klasik adalah uji normalitas dengan menggunakan one sample kolmogorov-smirnov test sebagai alat uji. Pada tabel 3 menunjukkan nilai signifikansi (sig.) 
hasil perhitungan one sample kolmogorov-smirnov test sebesar 0,200 dan nilai tersebut lebih besar dari 0,05. Apabila hasil signifikansi (Sig.) lebih besar dari 0,05 dapat disimpulkan bahwa pada penelitian ini datanya berdistribusi secara normal.

\section{Uji Autokorelasi}

Tabel 4. Hasil Uji Autokorelasi

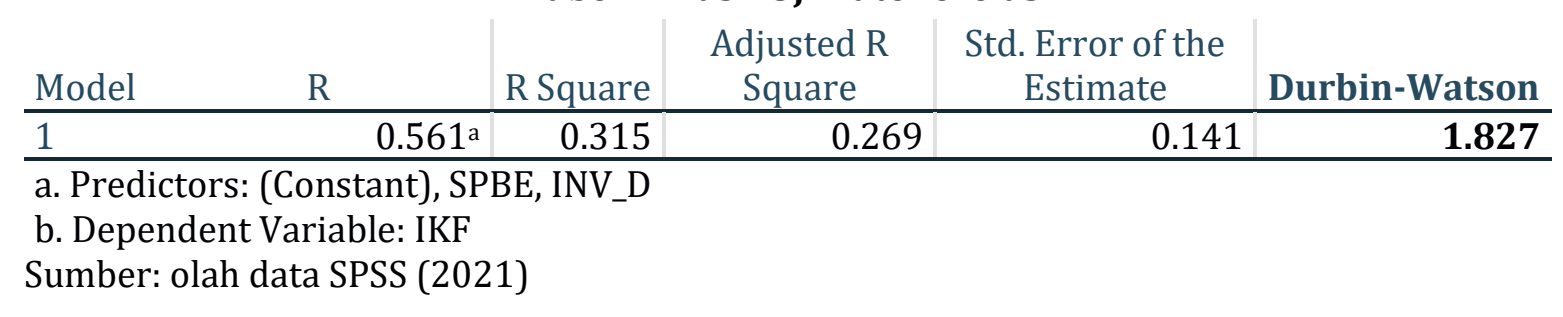

Pengujian kedua adalah uji autokorelasi Durbin-Watson. Pada tabel 4 terlihat nilai DurbinWatson (d) adalah 1,827, apabila dibandingkan dengan tabel Durbin-Watson untuk mencari nilai batas atas $(\mathrm{dU})$ dengan $\mathrm{n}=33$; $\mathrm{k}$ (jumlah sampel independent) $=2$ maka didapat nilai sebesar 1,50784 yang berarti nilai Durbin-Watson (d) > dari dU. Kemudian kita mencari nilai (4-dU) maka akan didapat hasil $4-1.50784=2,4921$. Sehingga didapatkan nilai Durbin-Watson yang dihasilkan terletak antara nilai dU dan nilai (4-dU) atau 1,50784 <1,827 <2,4921, sehingga bisa disimpulkan tidak terjadinya autokorelasi.

\section{Uji Multikolinearitas}

Tabel 5. Hasil Uji Multikolinearitas

\begin{tabular}{llrrrr}
\hline & & \multicolumn{2}{c}{ Unstandardized Coefficients } & \multicolumn{2}{c}{ Collinearity Statistics } \\
\cline { 2 - 5 } Model & \multicolumn{1}{c}{ B } & Std. Error & \multicolumn{1}{c}{ Tolerance } & \multicolumn{1}{c}{ VIF } \\
\hline \multirow{2}{*}{1 (Constant) } & 0.183 & 0.088 & & \\
\cline { 2 - 5 } & $6.265 \mathrm{E}-9$ & 0.000 & 0.915 & 1.093 \\
\cline { 2 - 5 } & INV_D & 0.064 & 0.035 & 0.915 & 1.093 \\
\hline
\end{tabular}

Sumber: olah data SPSS (2021)

Selanjutnya dilakukan pengujian multikolinearitas, yang tujuannya untuk menguji antara masing-masing variabel independent apakah terdapat korelasi atau tidak, karena seharusnya tidak ada korelasi di antara variabel independen di model regresi yang baik (Chandrarin, 2017). Pada tabel 5 hasil untuk nilai tolerance serta VIF untuk masing-masing variabel INV_D (investasi daerah) dan SPBE adalah sebesar 0,915 dan 1,093. Sebagai dasar pengambilan keputusan pengujian multikolinearitas bahwa nilai tolerance harus $>$ dari 0,10 dan nilai VIF harus < nilai 10,00. Jika melihat hasil tersebut maka dapat disimpulkan bahwa tidak terjadinya suatu gejala multikolinearitas dalam model regresi pada penelitian ini.

\section{Uji Heteroskedastisitas}

Tabel 6. Uji Heteroskedastisitas

\begin{tabular}{|c|c|c|c|c|c|c|}
\hline \multirow[b]{3}{*}{ Model } & & \multicolumn{5}{|c|}{ Standardized } \\
\hline & & \multicolumn{2}{|c|}{ Unstandardized Coefficients } & Coefficients & $\mathrm{t}$ & Sig. \\
\hline & & B & Std. Error & Beta & & \\
\hline 1 & (Constant) & 0.130 & 0.055 & & 2.359 & 0.025 \\
\hline & INV_D & $-4.394 \mathrm{E}-10$ & 0.000 & -0.055 & -0.289 & 0.775 \\
\hline
\end{tabular}




\section{a. Dependent Variable: ABS_RES}

Sumber: olah data SPSS (2021)

Pengujian keempat dari uji asumsi klasik adalah dilakukannya uji heteroskedastisitas dengan menggunakan uji glejser, karena model regresi yang baik seharusnya tidak terjadi gejala heteroskedastisitas. Hasil pengujian heteroskedastisitas dengan uji glejser menghasilkan nilai signifikan untuk variabel INV_D (X1) sebesar 0,775 dan untuk variabel SPBE (X2) sebesar 0,665. Sebagai dasar keputusan bahwa apabila nilai signifikan (sig.) > dari 0,05 berarti tidak terjadi gejala heteroskedastisitas dan dari nilai tersebut dapat ditarik kesimpulan tidak terjadi gejala heteroskedastisitas pada penelitian ini. Dari hasil pengujian asumsi klasik maka dapat dilanjutkan dengan analisis regresi linier berganda.

\section{Uji Regresi}

Dilakukannya uji $\mathrm{F}$ bertujuan melihat apakah variabel independen (investasi daerah dan $e$ government) secara bersama-sama atau simultan berpengaruh terhadap variabel dependen (kemandirian daerah). Dasar pengambilan kesimpulan dalam uji $\mathrm{F}$ adalah dengan melihat hasil dari nilai signifikansi atau dengan membandingkan nilai $\mathrm{F}$ hitung dengan $\mathrm{F}$ tabel. Jika hasil signifikansi (sig.) $<0,05$ maka hipotesis penelitian yang diajukan dapat diterima namun apabila hasil signifikansi (sig.) > 0,05 maka hipotesis penelitian yang diajukan ditolak. Jika dasar pengambilan kesimpulan dengan menggunakan $\mathrm{F}$ hitung maka berlaku ketentuan yaitu jika nilai $\mathrm{F}$ hitung > F tabel maka hipotesis yang diajukan dapat diterima dan sebaliknya.

Tabel 7. Uji F-statistik

\begin{tabular}{llrrrrr}
\hline Model & Sum of Squares & df & Mean Square & F & Sig. \\
\hline 1 & Regression & 0.274 & 2 & 0.137 & $\mathbf{6 . 8 9 0}$ & $\mathbf{0 . 0 0 3}^{\mathbf{b}}$ \\
& Residual & 0.596 & 30 & 0.020 & & \\
Total & 0.870 & 32 & & & \\
\hline
\end{tabular}

a. Dependent Variable: IKF

b. Predictors: (Constant), SPBE, INV_D

Sumber: olah data SPSS (2021)

Hasil pengujian uji F pada tabel 7 menghasilkan nilai signifikansi (sig.) sebesar 0,003, dan nilai tersebut $<0,05$ sehingga dapat ditarik kesimpulan yaitu variabel $\mathrm{X}_{1}$ atau investasi daerah dan variabel $\mathrm{X}_{2}$ atau e-government berpengaruh secara simultan/bersama-sama terhadap variabel $\mathrm{Y}$ atau Indeks Kemandirian Fiskal.

Setelah dilakukan pengujian uji $\mathrm{F}$ dan didapatkan kesimpulan atas hasil tersebut selanjutnya adalah memaknai hasil dari koefisien determinasi (R square). Nilai R square dapat dimaknai sebagai kontribusi pengaruh yang dapat diberikan oleh variabel independen terhadap variabel dependen. Hasil R square pada penelitian kali ini adalah sebesar 0,315 atau 31,5 persen (lihat tabel 4) dan dapat diartikan bahwa variabel investasi daerah dan implementasi SPBE secara simultan berpengaruh sebesar 31,5 persen terhadap variabel Indeks Kemandirian Fiskal, sedangkan sisanya sebesar 68,5 persen dipengaruhi oleh variabel lain yang tidak diteliti dalam penelitian ini.

\section{Uji Hipotesis}




\begin{tabular}{|c|c|c|c|c|c|}
\hline \multirow[b]{2}{*}{ Model } & \multicolumn{2}{|c|}{$\begin{array}{l}\text { Unstandardized } \\
\text { Coefficients } \\
\end{array}$} & \multirow{2}{*}{$\begin{array}{c}\begin{array}{c}\text { Standardized } \\
\text { Coefficients }\end{array} \\
\text { Beta }\end{array}$} & \multirow[b]{2}{*}{$\mathrm{t}$} & \multirow[b]{2}{*}{ Sig. } \\
\hline & $\mathrm{B}$ & Std. Error & & & \\
\hline 1 (Constant) & 0.183 & 0.088 & & 2.073 & 0.047 \\
\hline INV_D & $6.265 \mathrm{E}-9$ & 0.000 & 0.406 & 2.570 & 0.015 \\
\hline SPBE & 0.064 & 0.035 & 0.287 & 1.815 & 0.080 \\
\hline
\end{tabular}

Sumber: olah data SPSS (2021)

\section{Pengaruh Investasi Daerah terhadap Kemandirian Daerah}

Ruliana (2015) serta Normalita \& Mahmud (2017) menyatakan bahwa tingkat kemandirian pemerintah daerah dapat dilakukan melalui peningkatan realisasi pendapatan daerah. Semakin tinggi penerimaaan pendapatan asli daerah maka daerah tersebut akan semakin berkurang terhadap kebutuhan pendanaan yang berasal dari pemerintah pusat. Hal tersebut tentu akan berdampak baik di mana pemerintah pusat dapat mengalokasikan dananya ke daerah lain yang lebih membutuhkan sehingga dapat mengurangi kesenjangan fiskal dan bagi pemerintah daerah akan lebih leluasa dalam mengelola keuangannya yang ditujukan untuk membangun daerahnya sesuai dengan preferensi warga. Upaya dalam mengoptimalkan peningkatan pendapatan asli daerah dapat dilakukan dengan cara berinvestasi.

Investasi daerah pada penelitian ini dicerminkan dengan jumlah investasi jangka panjang (non permanen dan permanen) yang terdapat di Laporan Neraca sebagai salah satu laporan dalam Laporan Keuangan Pemerintah Daerah. Investasi tersebut dilakukan pemerintah daerah dengan tujuan untuk memperoleh manfaat di kemudian hari yang dapat berkontribusi terhadap penerimaan daerah. Investasi dapat dilakukan dengan berbagai bentuk dan salah satu caranya dengan penyertaan modal terhadap Badan Usaha Milik Daerah. Tujuan didirikannya perusahaan daerah adalah untuk mencari laba (Nugraha, 2019) dan diharapkan laba tersebut dapat membantu peningkatan pendapatan daerah.

Pada tabel 8, hasil uji t-statistik untuk nilai signifikansi variabel investasi daerah $\left(\mathrm{X}_{1}\right)$ sebesar 0,015. Sebagai dasar dalam pengambilan kesimpulan pada uji t adalah apabila nilai signifikansi (sig.) $<0,05$ maka hipotesis yang diajukan dapat diterima dan jika > 0,05 maka ditolak. Karena nilai 0,015 < 0,05 maka dapat disimpulkan bahwa investasi daerah memiliki pengaruh secara signifikan terhadap kemandirian daerah. Sehingga hipotesis yang diajukan dapat diterima.

Hasil penelitian ini mendukung hasil penelitian yang didapat oleh Mirsan et al (2019) yang menyatakan bahwa investasi berpengaruh positif terhadap derajat kemandirian fiskal daerah. Investasi yang dilakukan pemerintah terhadap Badan Usaha Milik Daerah mampu memberikan peningkatan modal sehingga BUMD tersebut dapat meningkatkan kapasitas produksinya, baik itu dari segi barang maupun jasa. Kapasitas produksi yang meningkat berarti peningkatan juga dalam output yang dihasilkan untuk kemudian dijual dan diharapkan mendapatkan keuntungan yang maksimal. Keuntungan yang dihasilkan tersebut tentu akan sangat berkontribusi terhadap pendapatan daerah. Hasil penelitian ini juga sejalan dengan penelitian yang dilakukan oleh Ririn et al (2014) dan Batik (2013), yang menyatakan bahwa investasi berpengaruh secara positif terhadap peningkatan asli daerah, semakin tinggi nilai investasi maka semakin tinggi pula pendapatan asli daerah dan secara langsung akan berdampak pada kemandirian daerah.

Hasil ini menunjukkan perlunya pemerintah daerah dalam menyisihkan sebagian dananya untuk berinvestasi pada BUMD. BUMD memiliki peran penting dalam peningkatan ekonomi daerah serta dapat memberikan pelayanan publik yang tidak bisa diberikan oleh pemerintah daerah selama ini.

\section{Pengaruh e-government terhadap Kemandirian Daerah}




\section{0 | Bina Ekonomi}

E-Government secara sederhana dapat didefinisikan sebagai adanya penggunaan teknologi informasi dan komunikasi di dalam kegiatan pemerintahan. Digunakannya teknologi ini diharapkan adanya perubahan proses kerja yang lebih efektif, efisiensi, perbaikan tata kelola dan peningkatan kinerja. Penggunaan teknologi di pemerintahan diharapkan akan membuat pemerintah lebih responsif dan terbuka kepada masyarakat sehingga membuat masyarakat lebih mudah memberikan umpan balik kepada pemerintah. Teknologi juga dapat membuat jangkauan pelayanan publik menjadi luas.

Salah satu tujuan dari implementasi SPBE adalah untuk mendorong dalam perubahan cara kerja dari yang semula manual menjadi elektronik, termasuk dalam bertransaksi keuangan di pemerintahan. Pemerintah saat ini dituntut untuk bisa menghadirkan layanan pembayaran pajak/retribusi seperti ketika masyarakat menggunakan aplikasi perbankan atau seperti ketika sedang berbelanja online. Proses di mana perusahaan yang sukses telah bertransisi menuju kematangan digital sedang direplikasi di sektor publik (Benjamin \& Potts, 2018). Oleh karenanya salah satu urusan pemerintahan yang akan terdampak adalah dalam pelayanan pajak/retribusi daerah. Pembayaran pajak/retribusi dimungkinkan menjadi lebih mudah, cukup dengan membuka aplikasi dari smartphone yang terhubung ke internet maka sudah dapat dilakukan pembayaran pajak/retribusi daerah. Kemudahan yang ditawarkan serta adanya efisiensi dari segi waktu dan biaya diharapkan dapat meningkatkan partisipasi masyarakat dalam membayar pajak daerah, yang kemudian tercermin dalam peningkatan PAD. Peningkatan kontribusi PAD dalam pendapatan daerah tentu akan membuat daerah tersebut mandiri secara fiskal. Pengelolaan pajak/retribusi daerah secara elektronik juga dapat meminimalkan kebocoran pajak/retribusi dan juga mengurangi kecurangan dalam pengelolaan keuangan daerah.

Pada tabel 8, hasil uji t-statistik untuk variabel SPBE $\left(\mathrm{X}_{2}\right)$ adalah sebesar 0,080. Sebagai dasar dalam pengambilan kesimpulan pada uji t-statistik adalah apabila nilai signifikansi (sig.) lebih kecil dari 0,05 maka hipotesis yang diajukan diterima dan jika sebaliknya maka ditolak. Karena nilai 0,80 > 0,05 maka dapat ditarik kesimpulan bahwa implementasi e-government tidak berpengaruh secara signifikan terhadap kemandirian daerah. Sehingga hipotesis yang diajukan, ditolak.

Hasil penelitian mendukung hasil penelitian yang dilakukan oleh Hanum (2020) yang menyatakan bahwa hasil nilai Indeks SPBE (e-government) tidak memiliki hubungan dengan pendapatan asli daerah (PAD) selaku faktor penentu dalam kemandirian daerah. Hasil ini bisa disebabkan oleh beberapa faktor dan salah satunya adalah tingkat kematangan Indeks SPBE yang masih berada pada nilai 2,46 atau dengan predikat cukup. Pada tingkat ini tentu pelaksanaan SPBE masih banyak kekurangan/kendala, seperti yang ditemukan dari hasil penelitian yang dilakukan oleh Avianto \& Amelia (2021) yang menemukan bahwa faktor implementasi $e$ government belum dapat berjalan optimal adalah infrastruktur yang tidak memadai, pemahaman user yang kurang memadai dalam menggunakan perangkat maupun aplikasi dan ketersediaan dana yang belum memadai.

\section{SIMPULAN}

Berdasarkan hasil analisis pada penelitian ini, menunjukkan bahwa investasi daerah di berbagai Provinsi di Indonesia berpengaruh positif dan mampu meningkatkan nilai Indeks Kemandirian Fiskal. Artinya dengan dilakukannya penyertaan modal oleh pemerintah daerah kepada Badan Usaha Milik Daerah mampu memberikan kontribusi terhadap peningkatan pendapatan asli daerah sebagai salah satu faktor penting dalam kemandirian daerah. Oleh karena itu disarankan kepada pemerintah daerah untuk membantu BUMD dengan meningkatkan nilai investasinya. Namun pemerintah daerah juga perlu melakukan analisis yang mendalam sebelum diambil keputusan investasi dengan mempertimbangkan Badan Usaha Milik Daerah mana yang 
mempunyai produktivitas, tata kelola dan kondisi keuangan yang baik sehingga mampu menghasilkan laba yang tinggi. Pemerintah daerah juga perlu meningkatkan semangat berwirausaha bagi BUMD (Suratno, 2018), selain itu pemerintah daerah perlu melakukan pengawasan dan evaluasi secara komprehensif terhadap kondisi Badan Usaha Milik Daerah, sehingga akan membantu dalam meningkatkan kinerjanya.

Hasil penelitian terhadap variabel e-governmnt yang diukur dengan hasil nilai Indeks SPBE di tingkat Provinsi di Indonesia ternayata belum mampu berkontribusi dalam kemandirian daerah. Potensi e-government untuk dapat berkontribusi berdasarkan literatur sebenarnya ada namun dalam konteks penerapannya di Indonesia diperlukan perbaikan dan peningkatan di sejumlah hal, seperti perlu ditingkatkannya standar pelayanan SPBE yang dapat berlaku secara menyeluruh dan bukan hanya sebatas pada tingkat unit organisasi. Sosialisasi terkait standar nasional SPBE serta evaluasi secara mendalam dan terus menerus dinilai mampu untuk meningkatkan layanan SPBE di Indonesia. Kolaborasi antara pemerintah pusat dan daerah dalam mengadakan infrastruktur teknologi diharapkan dapat mengurangi ketimpangan/kesenjangan yang terjadi di berbagai wilayah di Indonesia. Selain itu, disarankan juga untuk dapat menghadirkan layanan SPBE yang dapat memudahkan masyarakat mendapatkan pelayanan publik dari pemerintah. Kemudahan tersebut diharapkan mampu mendorong masyarakat untuk lebih berpartisipasi/berkontribusi dalam membangun daerahnya dan salah satunya tercermin dalam peningkatan asli daerah. Hadirnya SPBE sangat penting terlebih lagi saat ini Indonesia sedang berupaya menghadirkan smart city, dan perubahan tersebut harus dimulai dari pemerintah.

Keterbatasan pada penelitian ini adalah jangka waktu yang digunakan dalam penelitian yang hanya menggunakan data tahun 2019, dikarenakan data tahun 2020 tidak ada/tidak lengkap. Bagi penelitian ke depannya disarankan untuk menambah variabel lain, baik itu dari segi internal maupun eksternal. Karena kemandirian daerah dapat disebabkan banyak faktor baik secara mikro maupun makro ekonomi.

\section{DAFTAR PUSTAKA}

Ahmad, I. (2011). Regional Fiscal Independence in East Java Province Post Regional Autonomy. Economic Journal of Emerging Markets , 3(2), 189-198.

Andriani, R. N. R., \& Wahid, N. N. (2018). Pengaruh Pendapatan Asli Daerah dan Dana Perimbangan Terhadap Kemandirian Keuangan Daerah (Studi Kasus Pada Pemerintah Kota Tasikmalaya Tahun 2006 - 2015). Jurnal Akuntansi, 13(1), 30-39.

Avianto, B. N., \& Amelia, N. (2021). Penerapan E-Government Melalui Sistem Informasi Pengendalian Tagihan (SINTAG) di Sekretariat Jenderal MPR RI. International Journal of Social and Public Administration, I No.I.

Badan Pemeriksa Keuangan Republik Indonesia. (2020). Laporan Hasil Reviu atas Kemandirian Fiskal Pemerintah Daerah Tahun Anggaran 2018 dan 2019.

Bahtiar, R., Myrna, R., \& Susanti, E. (2021). Digital Government Dalam Pembayaran Pajak Kendaraan Bermotor Berbasis Aplikasi SAMSAT Mobile Jawa Barat (SAMBARA) di Jawa Barat. Kolaborasi: Jurnal Administrasi Publik, 7(2), 230-253. https://doi.org/10.26618/kjap.v7i2.5675

Batik, K. (2013). Analisis Pengaruh Investasi, PDRB, Jumlah Penduduk, Penerimaan Pembangunan, dan Inflasi Terhadap Pendapatan Asli Daerah (PAD) di Kabupaten Lombok Barat. Jurnal Ekonomi Pembangunan, 11(1), 125-147.

Benjamin, K., \& Potts, H. W. (2018). Digital transformation in government: Lessons for digital health? DIGITAL HEALTH, 3, 1-5. https://doi.org/10.1177/2055207618759168 


\section{2 | Bina Ekonomi}

Chandrarin, G. (2017). Metode Riset Akuntansi Pendekatan Kuantitatif (3rd ed.). Salemba Empat.

Edmiston, K. D. (2003). State and Local E-government Prospects and Challenges. American Review of Public Administration, 33(1), 20-45. https://doi.org/10.1177/0275074002250255

Firdausy, C. M. (Ed.). (2017). Kebijakan \& Strategi Peningkatan Pendapatan Asli Daerah Dalam Pembangunan Nasional. Yayasan Pustaka Obor Indonesia.

Handayani, T. U., \& Erinos. (2020). Pengaruh Pendapatan Asli Daerah Dan Belanja Modal Terhadap Tingkat Kemandirian Keuangan Daerah Dengan Pertumbuhan Ekonomi Sebagai Variabel Moderating (Studi Empiris Pada Kabupaten/Kota di Provinsi Sumatera Barat Tahun 2015-2018). Jurnal Eksplorasi Akuntansi, 2(1), 2348-2361. http://jea.ppj.unp.ac.id/index.php/jea/issue/view/19

Jauhari, A., Basri, H., \& Shabri, M. (2015). Penerapan Good Governance Berbasis E-Government dan Reformasi Birokrasi dalam Rangka Meningkatkan Kinerja Satuan Kerja Pemerintah Aceh. Jurnal Magister Akuntansi, 4(3), 57-70.

Keputusan Presiden Republik Indonesia Nomor 3 Tahun 2021 Tentang Satuan Tugas Percepatan dan Perluasan Digitalisasi Daerah, (2021).

kominfo.go.id. (2019). Terapkan e-Government untuk Tingkatkan Layanan Publik. https://www.kominfo.go.id/content/detail/19786/terapkan-e-government-untuktingkatkan-layanan-publik/0/berita_satker

Kusmayadi, R. C. R. (2015). Kewenangan Pemerintah Daerah dalam Penyelenggaraan Investasi Daerah. Jurnal Pusaka, 3(1), 65-80.

Mangantar, M. (2018). An Analysis of the Government Financial Performance Influence on Community Welfare in North Sulawesi Province Indonesia. International Journal of Economics and Financial Issues, 8(6), 137-143. https://doi.org/10.32479/ijefi.6949

Manoharan, A. P., \& Ingrams, A. (2018). Conceptualizing E-Government from Local Government Perspectives. State and Local Government Review, 50(1), 56-66. https://doi.org/10.1177/0160323x18763964

Mardiasmo. (2018). Akuntansi Sektor Publik (1st ed.). CV. ANDI OFFSET.

Martini, R., Rachma Sari, K., \& Wayan Karman, I. (2019). Financial Independence of The South Sumatra Regional Government. 2nd Proceedings of the International Conference On Applied Science and Technology, 360-364. http://creativecommons.org/licenses/by-nc/4.0/

Maulizar, H., Rasyidin, M., \& Wahyuni, S. (2017). Pengaruh Penyertaan Modal Pemerintah Daerah. Jurnal Akuntansi Dan Pembangunan, 3(3).

merdeka.com. (2018). Tahun ini, BPPD akan tambah 375 mesin tapping box senilai Rp 3 miliar. https://bandung.merdeka.com/halo-bandung/tahun-ini-bppd-akan-tambah-375-mesintapping-box-senilai-rp-3-miliar-180420b.html

Mirsan, Muh. A., Hamzah, N., \& Sjufri, M. (2019). Pengaruh Investasi, PDRB Perkapita dan Pendapatan Asli Daerah Terhadap Derajat Kemandirian Fiskal (Studi Kasus Provinsi Sulawesi Selatan). PARADOKS Jurnal Ilmu Ekonomi, 2(2).

Ndaparoka, D. S. R., Rantelobo, A. T., \& Samadara, S. (2018). Model Pengukuran Kemampuan Keuangan Daerah Melalui Kemandirian Fiskal dan Derajat Ekonomi Untuk Meningkatkan Akuntabilitas dan Transparansi Anggaran Pendapatan dan Belanja (APBD) Pemerintah Kabupaten Sumba Barat. Jurnal Akuntansi, Keuangan Dan Audit, 3(1), 19-28.

Normalita, I. S., \& Mahmud, A. (2017). Accounting Analysis Journal Analysis of Capital Expenditure and Its Implications on Local Financial Independence. AAJ: Accounting Analysis Journal, 6(2), 219-228. http://journal.unnes.ac.id/sju/index.php/aaj

Nugraha, Y. N. (2019). Ketergantungan Fiskal Daerah Dalam Pelaksanaan Desentralisasi Fiskal di Indonesia. https://www.kemenkeu.go.id/publikasi/artikel-dan-opini/ketergantunganfiskal-daerah-dalam-pelaksanaan-desentralisasi-fiskal-di-indonesia/ 
Nurmiati, Diana, F., \& Murbayani. (2019). Kontribusi Badan Usaha Milik Daerah Terhadap Pendapatan Asli Daerah Kota Makassar. In Prosiding Seminar Nasional Universitas Indonesia Timur , 89-100.

Patarai, M. I. (2018). Kinerja Keuangan Daerah (2nd ed., Vol. 2). De La Macca.

Permenpanrb No 5 Tahun 2018, Peraturan Menteri Pendayagunaan Aparatur Negara dan Reformasi Birokrasi Republik Indonesia Nomor 5 Tahun 2018 tentang Pedoman Evaluasi Sistem Pemerintahan Berbasis Elektronik.

Perpres No 95 Tahun 2018, Peraturan Presiden Republik Indonesia Nomor 95 Tahun 2018 tentang Sistem Pemerintahan Berbasis Elektronik.

PP No 63 Tahun 2019, Peraturan Pemerintah Republik Indonesia Nomor 63 Tahun 2019 tentang Investasi Pemerintah.

Purwokoadi, S. (2014). Pengaruh Penerapan Aplikasi e-government Pembayaran Pajak Kendaraan Bermotor Terhadap Kinerja Cash Adminstration. DIA, Jurnal Administrasi Publik, 12(1), 1-18.

Rahmatunnisa, N. A. H., Suswondo, S., \& Supriatna, I. (2021). Analisis Efektivitas Pelayanan Permohonan Perizinan Mendirikan Bangunan Dengan Berbasis Elektronik Serta Kontribusinya Pada Pendapatan Asli Daerah. Indonesian Accounting Research Journal, 1(2), 317-327.

Ririn, T., Prihatni, R., \& Murdayanti, Y. (2014). Pengaruh Belanja Modal, Investasi, dan Produk Domestik Regional Bruto Terhadap Pendapatan Asli Daerah. Jurnal Ilmiah Wahana Akuntansi, 9(1), 36.

Rokhman, A. (2011). E-Government Adoption in Developing Countries; the Case of Indonesia. Journal of Emerging Trends in Computing and Information Sciences, 2(5), 228-236. http://www.cisjournal.org

Ruliana, T. (2015). Revenue Independence of East Kalimantan Province, Indonesian. Journal of $\begin{array}{llll}\text { Asian Scientific } & \text { Research, 340-348. }\end{array}$ https://doi.org/10.18488/journal.2/2015.5.7/2.7.340.348

Saleh, H. (2020). Determinan Faktor Penerimaan dan Kemandirian Keuangan Daerah di Kabupaten Pinrang Sulawesi Selatan. BINA Ekonomi, 24(1), 26-40.

Sari, P., Garvera, R. R., \& Sihabudin, A. A. (2018). What is the Contribution of Local Original Revenue to Regional Financial Independent? Journal of Public Administration Studies, 3(2), 78-81.

Sudaryo, Y., Sjarif, D., \& Sofiati, N. A. (2017). Keuangan di Era Otonomi Daerah (P. Christian, Ed.; 1st ed.). CV. ANDI OFFSET.

Suratno, A. P. S. (2018). Effect of Government Investment and Capital Participation on Local OwnSource Revenue: The Case of Indonesia. European Research Studies Journal, XXI(4), 368-377.

Sutopo, B., Wulandari, T. R., Adiati, A. K., \& Saputra, D. A. (2017). E-government, audit opinion, and performance of local government administration in Indonesia. Australasian Accounting, Business and Finance Journal, 11(4), 6-22. https://doi.org/10.14453/aabfj.v11i4.2

Tahar, A., \& Zakhiya, M. (2011). Pengaruh Pendapatan Asli Daerah dan Dana Alokasi Umum Terhadap Kemandirian Daerah dan Pertumbuhan Ekonomi Daerah. Jurnal Akuntansi Dan Investasi, 12(1), 88-99.

Tolosang, K. D. (2018). Pengaruh Pertumbuhan Ekonomi dan Pendapatan Asli Daerah Terhadap Tingkat Kemandirian Keuangan Daerah Kota Tomohon. Jurnal Berkala Ilmiah Efisiensi, 18(03).

Triyanto, H. (2017). Pengaruh Penyertaan Modal Daerah, Produk Domestik Regional Bruto, dan Jumlah Penduduk Usia Produktif Terhadap Pendapatan Asli Daerah Pada Kabupaten/ Kota Di Kalimantan Barat. Jurnal Ekonomi Daerah (JEDA), 5(3). 
134 | Bina Ekonomi

Twizeyimana, J. D., \& Andersson, A. (2019). The public value of E-Government - A literature review. In Government Information Quarterly (Vol. 36, Issue 2, pp. 167-178). Elsevier Ltd. https://doi.org/10.1016/j.giq.2019.01.001

Wahyono, D. (2021). Investasi Daerah dalam Teori Modernisasi. Kabilah: Journal of Social Community, 6(1).

Zulfikar, M. (2021). Pakar paparkan penyebab indeks kemandirian fiskal daerah rendah. https://www.antaranews.com/berita/2060118/pakar-paparkan-penyebab-indeks-

kemandirian-fiskal-daerah-rendah 